\title{
ANALISIS KONTRIBUSI PAJAK PARKIR DAN PAJAK RESTORAN DALAM RANGKA MENINGKATKAN PENDAPATAN ASLI DAERAH (PAD) JAKARTA TIMUR SERTA KONTRIBUSI TERHADAP PENDAPATAN ASLI DAERAH (PAD) DKI JAKARTA DALAM SEKTOR PAJAK PARKIR DAN PAJAK RESTORAN
}

\author{
Rina Hidayahti ${ }^{1)}$ Mulia Rahmah ${ }^{2)}$ \\ Program Studi Akuntansi Fakultas Ekonomi \\ Universitas Krisnadwipayana \\ rinahidayahti26@gmail.com ${ }^{1)}$ \\ muliarahmah@gmail.com²)
}

\begin{abstract}
This research is to find out how big the tax contribution of parking and restaurant in order to increase tax Income Native (PAD) in East Jakarta, as well as how large the tax contribution of parking and restaurant Tax Revenue against the Original East Jakarta area (PAD) DKI Jakarta in the tax sector, parking and restaurant tax. This research was conducted at the Suku Badan Pajak dan Retribusi Daerah. This research is a qualitative descriptive study. Data taken from the Regional Original Revenue Report (PAD) in the form of targets and realization of East Jakarta's parking tax and restaurant tax 2015-2017. The analysis used is descriptive analysis using the ratio of parking tax contribution and restaurant tax. Data collection in the study was obtained from observation, interviews and documentation. The conclusion of this study, shows that the average contribution given Parking Tax and Restaurant Tax in order to increase the East Jakarta Regional Original Revenue (PAD) in 2015-2017 is 0.88\% for Parking Tax with the criteria of "Very Less" and 4,88\% for Restaurant Tax with "Very Less" contribution criteria. Whereas the average contribution given by the East Jakarta Parking Tax and Restaurant Tax to the DKI Jakarta Original Regional Income (PAD) in the Parking Tax and Restaurant Tax sectors in 2015-2017 is 6.48\% for Parking Tax with the "Very Less" contribution criteria and $6.61 \%$ for Restaurant Tax with "Very Less" contribution criteria. Suggestions from this study, it is expected that East Jakarta Regional Tax and Retribution Agency must periodically re-record the parking taxpayer and restaurant, it is necessary to conduct socialization about the importance of compliance and awareness of taxpayers in making tax payments in accordance with the stipulated time and must be able to apply strict sanctions against taxpayers who are in arrears in order to achieve a deterrent effect on violators.
\end{abstract}

Keywords : Parking Tax, Restaurant Tax, Regional Original Revenue

\section{PENDAHULUAN}

Pelaksanaan Undang-Undang Nomor 32 Tahun 2004 tentang pemerintah daerah, telah menyebabkan perubahan yang mendasar mengenai pengaturan hubungan antara pemerintah pusat dan pemerintah daerah, khususnya dalam bidang keuangan antara pemerintah pusat dan pemerintah daerah, yang dikenal sebagai era otonomi daerah. Dalam era otonomi daerah sekarang ini, daerah diberikan kewenangan yang lebih besar untuk mengatur dan mengurus rumah tangganya sendiri, tujuannya antara lain adalah untuk mempercepat terwujudnya kesejahteraan masyarakat dengan lebih mendekatkan pelayanan pemerintah kepada masyarakat, memberdayakan masyarakat dan meningkatkan peran serta masyarakat.

Agar otonomi daerah dapat dilaksanakan sesuai dengan tujuan yang hendak dicapai, pemerintah daerah diharapkan mampu menggali sumber-sumber keuangan khususnya untuk memenuhi kebutuhan pembiayaan pemerintah daerah dan pembangunan di daerahnya melalui Pendapatan Asli Daerah (PAD). Sumbersumber pendapatan asli daerah yang potensial harus digali secara maksimal sesuai dengan ketentuan dan peraturan yang berlaku, termasuk diantaranya adalah pajak daerah.Pajak daerah merupakan salah satu komponen penyumbang terbesar dalam struktur Pendapatan Asli Daerah. Hasil 
pembayaran pajak nantinya akan dikembalikan kepada masyarakat dalam bentuk pembangunan di daerah yang dilaksanakan demi kesejahteraan masyarakat.

DKI Jakarta merupakan ibukota Negara Indonesia yang menjadi pusat pemerintahan dan pusat ekonomi dan bisnis sehingga menjadikan DKI Jakarta sebagai barometer perkembangan perekonomian nasional. DKI Jakarta mempunyai kegiatan utama yang paling dominan yaitu sebagai areal fungsional kota yang terdiri dari areal pemerintahan, perdagangan, perkantoran, industri, dan hunian. Keanekaragaman jenis dari ruang publik sebagai ruang aktifitas komersial tersebut menjadikan magnet bagi para pengunjung. Semakin banyak pengunjung yang datang, semakin tinggi pula jumlah kendaraan yang memadati jalanan kota DKI Jakarta sehingga kebutuhan lahan tertentu untuk keperluan parkir menjadi sangat diperlukan. Selain itu, semakin banyak pengunjung yang datang keberadaan restoran pun menjadi sangat diperlukan hal ini mendorong para pengusaha untuk membangun restoran-restoran karena DKI Jakarta memiliki pangsa pasar yang baik.

Kota Administrasi Jakarta Timur merupakan salah satu wilayah administrasi di bawah pemerintah Provinsi DKI Jakarta. Jakarta Timur sebagai bagian yang tak terpisahkan dari wilayah DKI Jakarta yang juga menjadi ibu kota Negara Indonesia dituntut untuk terus mengembangkan dirinya sesuai dengan dinamika pembangunan yang berkembang dan semakin maju. Secara demografis, Jakarta Timur memiliki wilayah yang paling luas di antara wilayah lainnya di Provinsi DKI Jakarta. Jakarta Timur juga memiliki jumlah penduduk yang paling banyak.

Perkembangan pembangunan di Jakarta Timur yang sangat pesat dewasa ini menyebabkan semakin bertambahnya penggunaan kendaraan bermotor, yang membawa dampak salah satunya pada keberadaan lahan perparkiran sebagai fasilitas yang amat diperlukan warga Jakarta Timur. Melihat potensi pajak parkir di Jakarta Timur yang cukup besar, namun ada kendala bagi pemerintah Jakarta Timur dalam melakukan pemungutan pajak parkir, salah satunya dikarenakan adanya proyek pembangunan infrastruktur pemerintah yang mempengaruhi okupansi lahan parkir.
Meningkatnya pembangunan di Jakarta Timur juga memungkinkan akan menjadi faktor-faktor penunjang pendapatan daerah khususnya dalam sektor pajak restoran. Jakarta Timur memiliki potensi yang besar pada sektor pajak restoran, karena Jakarta Timur merupakan wilayah yang paling padat penduduknya di antara wilayah lainnya di Provisi DKI Jakarta dan banyak anak muda yang setiap harinya menghabiskan waktu di tempat-tempat seperti caffe dan restoran yang terus di bangun di wilayah Jakarta Timur. Pembangunan pusat perbelanjaan di Jakarta Timur juga membuat para pengusaha tertarik untuk berinvestasi dan berlomba-lomba membuka usaha restoran, caffe, dan rumah makan yang cukup potensial untuk dikembangkan. Melihat potensi pajak restoran di Jakarta Timur yang cukup besar, namun ada kendala bagi pemerintah Jakarta Timur dalam melakukan pemungutan Pajak Restoran karena masih kurangnya kesadaran masyarakat untuk membayar pajak.

Berdasarkan data dari Suku Badan Pajak dan Retribusi Daerah Jakarta Timur, diperoleh data jumlah objek pajak parkir dan pajak restoran. Berikut adalah perkembangan jumlah objek pajak parkir dan pajak restoran di Jakarta Timur tahun 2015-2017 :

Tabel 1

Jumlah Objek Pajak Parkir dan Pajak Restoran di Jakarta Timur Tahun 2015-2017

\begin{tabular}{|c|c|c|}
\hline Tahun & $\begin{array}{c}\text { Pajak } \\
\text { Parkir }\end{array}$ & $\begin{array}{c}\text { Pajak } \\
\text { Restoran }\end{array}$ \\
\hline 2015 & 119 & 623 \\
\hline 2016 & 136 & 762 \\
\hline 2017 & 152 & 1013 \\
\hline
\end{tabular}
Administrasi Jakarta Timur (2015-2017)

Data dari Suku Badan Pajak dan Retribusi Daerah Kota Administrasi Jakarta Timur dari tahun 2015 sampai dengan tahun 2017 menunjukan jumlah objek pajak parkir dan pajak restoran selalu mengalami peningkatan. Hal ini menandakan semakin tingginya kebutuhan tempat parkir dan restoran di Jakarta Timur. Dengan adanya peningkatan jumlah tempat parkir dan restoran setiap tahunnya diharapkan dapat meningkatkan sumber penerimaan pajak 
daerah dan dapat memberikan kontribusi yang cukup potensial terhadap penerimaan Pendapatan Asli Daerah (PAD) di Jakarta Timur sehingga diharapkan tercapainya penerimaan Pendapatan Asli Daerah di Jakarta Timur sesuai dengan target yang sudah ditetapkan.

\section{TINJAUAN PUSTAKA \\ Pajak}

Menurut Undang-Undang No. 16 Tahun 2009 tentang perubahan keempat atas UndangUndang No. 16 Tahun 1983 tentang Ketentuan Umum dan Tata Cara Perpajakan pada Pasal 1 ayat 1 bahwa pajak adalah kontribusi wajib kepada Negara yang terutang oleh orang pribadi atau badan yang bersifat memaksa berdasarkan Undang-Undang, dengan tidak mendapatkan imbalan secara langsung dan digunakan untuk keperluan Negara bagi sebesar-besarnya kemakmuran rakyat.

\section{Pendapatan Asli Daerah (PAD)}

Menurut Undang-Undang Republik Indonesia Nomor 33 Tahun 2004 tentang Perimbangan Keuangan antara Pemerintah Pusat dan Daerah Pasal 1 butir (18) adalah adalah Pendapatan yang diperoleh daerah yang dipungut berdasarkan peraturan daerah sesuai dengan peraturan perundang-undangan.

\section{Pajak Parkir}

Sesuai dengan Peraturan Daerah Provinsi DKI Jakarta Nomor 16 Tahun 2010 tentang Pajak Parkir. Pengertian Pajak Parkir adalah pajak atas penyelenggaraan tempat parkir di luar badan jalan, baik yang disediakan berkaitan dengan pokok usaha maupun yang disediakan sebagai suatu usaha, termasuk penyediaan tempat penitipan kendaraan bermotor.

\section{Pajak Restoran}

Sesuai dengan Undang-Undang Republik Indonesia Nomor 28 Tahun 2009 tentang Pajak Daerah dan Retribusi Daerah, Pengertian Pajak Restoran adalah pajak atas pelayanan yang disediakan oleh restoran. Restoran adalah fasilitas penyedia makanan dan/atau minuman dengan dipungut bayaran, yang mencakup juga rumah makan, kafetaria, kantin, warung, bar, dan sejenisnya termasuk jasa boga atau catering

\section{Kontribusi}

Kontribusi adalah sumbangan, sokongan atau dukungan terhadap suatu kegiatan. Kontribusi merupakan suatu ukuran untuk mengetahui seberapa besar kontribusi yang dapat disumbangkan dari penerimaan pajak daerah dalam meningkatkan Pendapatan Asli Daerah (PAD). Kontribusi masing-masing jenis pajak daerah terhadap Pendapatan Asli Daerah (PAD) merupakan rasio antara jenis pajak tertentu dengan total Pendapatan Asli Daerah (PAD) pada satu tahun tertentu, dan rasio antara jumlah total pajak daerah terhadap total Pendapatan Asli Daerah (PAD) pada tahun tertentu. Untuk menghitung kontribusi pajak daerah maka membandingkan realisasi pajak daerah terhadap realisasi Pendapatan Asli Daerah (PAD). Tabel dibawah ini menggambarkan indikator dalam menilai kontribusi pajak daerah terhadap realisasi Pendapatan Asli Daerah (PAD).

Tabel 2 Klasifikasi Kriteria Kontribusi

\begin{tabular}{|c|c|}
\hline Persentase & Kriteria \\
\hline $0,00 \%-10 \%$ & Sangat Kurang \\
\hline $10,10 \%-20 \%$ & Kurang \\
\hline $20,10 \%-30 \%$ & Sedang \\
\hline $30,10 \%-40 \%$ & Cukup Baik \\
\hline $40,10 \%-50 \%$ & Baik \\
\hline $50,10 \%-$ Ke atas & Sangat Baik \\
\hline
\end{tabular}

Sumber (Depdagri, Kepmendagri No 690.900.327 : Tahun 1991

\section{METODOLOGI PENELITIAN Objek/Lokasi Penelitian Dan Waktu Penelitian}

Dalam penelitian ini yang menjadi objek penelitian adalah Pajak Parkir dan Pajak Restoran. Adapun penelitian ini dilakukan di Suku Badan Pajak dan Retribusi Daerah Wilayah Kota Administrasi Jakarta Timur yang berlokasi di Jalan D.I. Panjaitan Kav. 55, Jatinegara, Jakarta Timur 13410. Waktu penelitian ini dilaksanakan dari bulan Maret 2018 sampai dengan Agustus 2018.

\section{Populasi dan Sampel}

Populasi dalam penelitian ini adalah Laporan Pendapatan Asli Daerah (PAD) Kota Administrasi Jakarta Timur dan Laporan Pendapatan Asli Daerah (PAD) Provinsi DKI Jakarta.

Sampel dalam penelitian ini adalah target dan realisasi Pajak Parkir, Pajak Restoran, realisasi Pendapatan Asli Daerah (PAD) Kota Administrasi Jakarta Timur, 
target dan realisasi Pajak Parkir, dan Pajak Restoran DKI Jakarta tahun 2015-2017.

\section{Metode Pengumpulan Data}

Sumber data yang digunakan dalam penelitian ini adalah data sekunder. Data sekunder dalam penelitian ini merupakan data yang diambil dari catatan atau sumber lain yang telah ada yang sudah diolah oleh pihak ketiga, secara berkala (time series) untuk melihat perkembangan objek penelitian selama periode tertentu. Dalam penelitian ini data sekunder yang dikumpulkan adalah data realisasi penerimaan Pajak Parkir, Pajak Restoran dan data Pendapatan Asli Daerah (PAD). Metode pengumpulan data yang digunakan dalam penelitian ini adalah observasi, wawancara, dokumentasi

\section{Metode Analisi Data}

Setelah data penerimaan Pajak Parkir dan Pajak Restoran terkumpul kemudian dilakukan analisis data. Analisis Data yang digunakan dalam penelitian ini adalah dengan menggunakan analisis deskriptif kualitatif. Analisis berupa melihat kontribusi Pajak Parkir dan Pajak Restoran dalam rangka meningkatkan Pendapatan Asli Daerah (PAD) Jakarta Timur serta kontribusinya terhadap Pendapatan Asli Daerah (PAD) DKI Jakarta dalam sektor Pajak Parkir dan Pajak Restoran. Peneliti menggunakan metode analisis deskriptif berupa rasio. Analisis rasio yang digunakan adalah rasio kontribusi.

\section{HASIL DAN PEMBAHASAN}

\section{Target dan Realisasi Pajak Parkir Kota Administrasi Jakarta Timur}

Berikut ini adalah target dan realisasi pajak parkir Kota Administrasi Jakarta Timur tahun2015-2017.

Tabel 3
$\begin{gathered}\text { Target dan Realisasi Pajak Parkir Kota } \\
\text { Administrasi Jakarta Timur } \\
\text { Tahun 2015 -2017 }\end{gathered}$
\begin{tabular}{|c|c|c|}
\hline Tahun & $\begin{array}{c}\text { Target } \\
(\text { Rp) }\end{array}$ & $\begin{array}{c}\text { Realisasi } \\
\text { (Rp) }\end{array}$ \\
\hline 2015 & 18.200 .000 .000 & 21.933 .058 .028 \\
\hline 2016 & 27.428 .000 .000 & 28.167 .206 .549 \\
\hline 2017 & 45.642 .000 .000 & 41.486 .376 .306 \\
\hline
\end{tabular}

Sumber (Suku Badan Pajak Dan Retribusi Daerah Kota Administrasi Jakarta Timur)

Berdasarkan tabel 3 target dan realisasi penerimaan Pajak Parkir Jakarta
Timur tahun 2015-2017 semakin meningkat setiap tahunnya. Tahun 2015 target pajak parkir sebesar Rp. 18.200.000.000 dan realisasi penerimaan pajak parkir sebesar Rp. 21.933.058.028. Tahun 2016 realisasi penerimaan pajak parkir sebesar Rp. 28.167.206.549 dari target yang ditetapkan sebesar Rp. 27.428.000.000. Realisasi tersebut mengalami peningkatan sebesar Rp. 6.234.148.521 jika dibandingkan dengan realisasi Pajak Parkir tahun anggaran 2015 sebesar Rp. 21.933.058.028. Tahun 2017 realisasi penerimaan pajak parkir sebesar Rp. 41.486.376.306 dari target yang ditetapkan sebesar Rp. 45.642.000.000. Realisasi tersebut mengalami peningkatan sebesar Rp. 13.319.169.757 jika dibandingkan dengan realisasi Pajak Parkir tahun anggaran 2016 sebesar Rp. 28.167.206.549. Namun realisasi Pajak Parkir tahun anggaran 2017 tersebut belum mencapai target yang ditetapkan.

Berdasarkan hasil wawancara dengan Badan Pajak dan Retribusi Daerah Provinsi DKI Jakarta dengan Bidang Pengendalian, pada tahun 2017 realisasi penerimaan Pajak Parkir belum mencapai target yang ditetapkan salah satu faktornya dikarenakan adanya proyek pembangunan infrastruktur pemerintah yang mempengaruhi okupansi lahan parkir sehingga mengakibatkan 13 objek pajak parkir di Jakarta Timur sudah tidak beroperasi lagi, serta masih kurangnya kesadaran masyarakat 
sebagai wajib pajak untuk membayar pajak kepada daerah.

\section{Tabel 4}

\section{Jumlah Objek Pajak Parkir Kota} Administrasi Jakarta Timur Tahun 2015 - 2017

\begin{tabular}{|c|c|}
\hline Tahun & $\begin{array}{c}\text { Objek Pajak } \\
\text { Parkir }\end{array}$ \\
\hline 2015 & 119 \\
\hline 2016 & 136 \\
\hline 2017 & 152 \\
\hline
\end{tabular}

Sumber (Suku Badan Pajak dan Retribusi Daerah Kota Administrasi Jakarta Timur)

Berdasarkan tabel 4 jumlah objek Pajak Parkir Jakarta Timur tahun 2015-2017 mengalami peningkatan setiap tahunnya. Jumlah objek Pajak Parkir tahun 2015 sebanyak 119 objek pajak. Tahun 2016 jumlah objek Pajak Parkir mengalami peningkatan sebanyak 136 objek pajak. Dan pada tahun 2017 jumlah objek Pajak Parkir kembali mengalami peningkatan sebanyak 152 objek pajak. Jumlah objek pajak parkir untuk tahun 2015-2017 mengalami peningkatan namun ada kemungkinan sebagian masih memiliki tunggakan sehingga realisasinya pada tahun 2017 belum mencapai target yang ditetapkan.

\section{Target dan Realisasi Pajak Restoran Kota} Administrasi Jakarta Timur

Berikut ini adalah target dan realisasi pajak restoran Kota Administrasi Jakarta Timur tahun 2015-2017

Tabel 5

Target dan Realisasi Pajak Restoran Kota Administrasi Jakarta Timur Tahun 2015 - 2017

\begin{tabular}{|c|c|c|}
\hline Tahun & $\begin{array}{c}\text { Target } \\
(\mathbf{R p})\end{array}$ & $\begin{array}{c}\text { Realisasi } \\
(\mathbf{R p})\end{array}$ \\
\hline 2015 & 119.385 .000 .000 & 120.367 .066 .166 \\
\hline 2016 & 149.195 .000 .000 & 156.577 .884 .159 \\
\hline 2017 & 202.702 .000 .000 & 225.860 .742 .835 \\
\hline
\end{tabular}

Sumber (Suku Badan Pajak dan Retribusi Daerah Kota Administrasi Jakarta Timur)

Berdasarkan tabel 5 target dan realisasi penerimaan Pajak Restoran Jakarta Timur tahun

2015-2017 semakin meningkat setiap tahunnya. Tahun 2015 target pajak restoran sebesar Rp. 119.385.000.000 dan realisasi penerimaan Pajak Restoran sebesar Rp. 120.367.066.166. Tahun 2016 realisasi penerimaan Pajak Restoran sebesar Rp. 156.577.884.159 dari target yang ditetapkan sebesar Rp. 149.195.000.000. Realisasi tersebut mengalami peningkatan sebesar Rp. 36.210.817.993 jika dibandingkan dengan realisasi Pajak Restoran tahun anggaran 2015 sebesar Rp. 120.367.066.166. Tahun 2017 realisasi penerimaan Pajak Restoran sebesar Rp. 225.860.742.835 dari target yang ditetapkan sebesar Rp. 202.702.000.000. Realisasi tersebut mengalami peningkatan sebesar Rp. 69.282.858.676 jika dibandingkan dengan realisasi Pajak Restoran tahun anggaran 2016 sebesar Rp. 156.577.884.159.

Berdasarkan hasil wawancara dengan Suku Badan Pajak dan Retribusi Daerah Jakarta Timur dengan Bidang Penetapan dan Penagihan, peningkatan target dan realisasi penerimaan Pajak Restoran dikarenakan adanya evaluasi target dan tercapainya realisasi penerimaan Pajak Restoran. Tercapainya realisasi penerimaan Pajak Restoran dikarenakan adanya perkembangan jumlah objek Pajak Restoran di Jakarta Timur yang semakin meningkat setiap tahunnya.

Tabel 6

Jumlah Objek Pajak Restoran Kota Administrasi Jakarta Timur Tahun 2015 - 2017

\begin{tabular}{|c|c|c|c|c|}
\hline No & Klasifikasi & 2015 & 2016 & 2017 \\
\hline 1 & Café & 38 & 54 & 94 \\
\hline 2 & Caffee Shop & 16 & 21 & 41 \\
\hline 3 & Fast Food & 24 & 28 & 59 \\
\hline 4 & Kantin & 47 & 52 & 55 \\
\hline 5 & Katering & 21 & 28 & 31 \\
\hline 6 & Restoran & 243 & 288 & 372 \\
\hline 7 & Rumah Makan & 234 & 291 & 361 \\
\hline \multicolumn{2}{|r|}{ Jumlah } & 623 & 762 & 1.013 \\
\hline
\end{tabular}

Sumber (Suku Badan Pajak dan Retribusi Daerah Kota Administrasi Jakarta Timur)

Berdasarkan tabel 6 jumlah objek Pajak Restoran Jakarta Timur tahun 2015-2017 mengalami peningkatan setiap tahunnya. Jumlah objek Pajak Restoran tahun 2015 sebanyak 623 
objek pajak. Di tahun 2016 jumlah objek Pajak Restoran mengalami peningkatan sebanyak 762 objek pajak. Dan pada tahun 2017 jumlah objek Pajak Restoran bertambah ebanyak 1.013 objek pajak.

\section{Realisasi Pendapatan Asli Daerah (PAD) Kota Administrasi Jakarta Timur}

Berikut ini adalah realisasi Pendapatan Asli Daerah (PAD) Jakarta Timur tahun 20152017

\section{Tabel 7}

Realisasi Pendapatan Asli Daerah (PAD) Kota Administrasi Jakarta Timur Tahun 2015 - 2017

\begin{tabular}{|c|c|}
\hline Tahun & $\begin{array}{c}\text { Realisasi PAD } \\
\text { Jakarta Timur(Rp) }\end{array}$ \\
\hline 2015 & 2.872 .886 .648 .549 \\
\hline 2016 & 3.419 .523 .615 .902 \\
\hline 2017 & 3.819 .775 .386 .632 \\
\hline
\end{tabular}

Sumber (BPKD Kota Administrasi Jakarta Timur)

Berdasarkan tabel 7 Realisasi Pendapatan Asli Daerah (PAD) Jakarta Timur semakin meningkat setiap tahunnya. Realisasi PAD tahun anggaran 2015 sebesar Rp. 2.872.886.648.549,53. Sedangkan realisasi PAD tahun anggaran 2016 sebesar Rp. 3.419.523.615.902. Realisasi tersebut mengalami peningkatan sebesar Rp. 546.636.967.353 jika dibandingkan dengan realisasi PAD tahun anggaran 2015 sebesar Rp. 2.872.886.648.549. Realisasi PAD tahun anggaran 2017 sebesar Rp. 3.819.775.386.632. Realisasi tersebut mengalami peningkatan sebesar Rp. 400.251.770.730 jika dibandingkan dengan realisasi PAD tahun anggaran 2016 sebsar Rp. 3.419.523.615.902.

Tidak adanya target Pendapatan Asli Daerah di Kota Administrasi Jakarta Timur dikarenakan perwilayah di DKI Jakarta semua dilimpahkan dan dikelola oleh Provinsi. Peningkatan realisasi penerimaan PAD dari tahun ke tahun dikarenakan adanya peningkatan realisasi penerimaan pajak daerah yang memberikan peran penting dalam menyumbangkan untuk meningkatkan PAD Jakarta Timur.
Target dan Realisasi Pajak Parkir Provinsi DKI Jakarta

Berikut ini adalah target dan realisasi pajak parkir Provinsi DKI Jakarta tahun 20152017.

\section{Tabel 8}

Target dan Realisasi Pajak Parkir Provinsi DKI Jakarta

Tahun 2015 - 2017

\begin{tabular}{|c|c|c|}
\hline Tahun & Target (Rp) & Realisasi (Rp) \\
\hline $\mathbf{2 0 1 5}$ & 425.000 .000 .000 & 450.941 .851 .356 \\
\hline $\mathbf{2 0 1 6}$ & 500.000 .000 .000 & 465.990 .849 .020 \\
\hline $\mathbf{2 0 1 7}$ & 500.000 .000 .000 & 484.833 .460 .923 \\
\hline
\end{tabular}

Sumber : Badan Pajak dan Retribusi Daerah Provinsi DKI Jakarta

Berdasarkan tabel 8 pada tahun 2015-2017 target dan realisasi penerimaan Pajak Parkir realisasi Pajak Parkir tahun anggaran 2015 sebesar 450.941.851.356 dari target yang ditetapkan sebesar Rp. 425.000.000.000. Realisasi Pajak Parkir tahun anggaran 2016 sebesar 465.990.849.020 dari target yang ditetapkan sebesar Rp. 500.000.000.000. Realisasi tersebut mengalami peningkatan sebesar Rp. 15.048.997.664 jika dibandingkan dengan realisasi Pajak Parkir tahun anggaran 2015 sebesar Rp.450.941.851.356. Namun realisasi Pajak Parkir tahun anggaran 2016 tersebut belum mencapai target yang ditetapkan. Realisasi Pajak Parkir tahun anggaran 2017 sebesar Rp. 484.833.460.923 dari target yang ditetapkan sebesar Rp. 500.000.000.000. Target Pajak Parkir tahun 2017 tidak dinaikan dikarenakan realisasi penerimaan Pajak Parkir tahun 2016 masih jauh dari target yang di tetapkan. Realisasi tahun 2017 mengalami peningkatan sebsar Rp. 18.842.611.903 jika dibandingkan dengan realisasi Pajak Parkir tahun anggaran 2016 sebesar Rp. 465.990.849.020. Namun realisasi Pajak Parkir tahun anggaran 2017 tersebut masih belum mencapai target yang ditetapkan.

Berdasarkan hasil wawancara dengan Badan Pajak dan Retribusi Daerah dengan Bidang Perencanaan dan Pengembangan, dalam menentukan target atau potensi Pajak Parkir DKI Jakarta menggunakan rumus yang telah ditetapkan pada Surat Keputusan Kepala Dinas 
Pelayanan Pajak Provinsi DKI Jakarta nomor 376 tahun 2013 yaitu,

\section{$\left\{\left(\mathrm{JP}_{1} \times \mathrm{TP}_{1} \times \mathrm{TO}\right)+\left(\mathbf{J P} \times \mathbf{T P}_{2} \times(\mathrm{JO}-1)\right)\right\} \times \mathbf{A R} \times$} $H \times$ Tarif Pajak Parkir

$\begin{array}{ll}\text { Keterangan : } \\ \text { JP } \quad \text { Jumlah Marka Parkir Mobil } \\ & \text { dan Motor } \\ \mathrm{TO}= & \text { Turn Over } \\ \mathrm{TP}_{1}= & \text { Tarif Parkir Mobil dan Motor } \\ & \text { Jam Pertama } \\ \mathrm{TP}_{2}= & \text { Tarif Parkir Mobil dan Motor } \\ & \text { Jam Kedua dst } \\ \mathrm{JO} & =\text { Jam Operasional } \\ \mathrm{AR} & =\text { Akupansi Rate } \\ \mathrm{H} & = \\ & \text { Jumlah Hari Operasional } \\ & \text { Dalam 1 Tahun }\end{array}$

Berdasarkan hasil wawancara dengan Badan Pajak dan Retribusi Daerah Provinsi DKI Jakarta dengan Bidang Perencanaan dan Pengembangan, tidak tercapainya realisasi penerimaan Pajak Parkir tahun 2016 dan 2017 dikarenakan adanya perubahan dasar pengenaan pajak, yaitu sebelumnya tarif pajak parkir sudah termasuk pajak dan asuransi (included tax) kemudian menjadi tidak termasuk asuransi (excluded tax) dimana nilai tarif sebagai pengalinya mengalami penurunan, banyaknya proyek pembangunan infrastruktur pemerintah yang mempengaruhi okupansi lahan parkir sehingga mengakibatkan pada tahun 2016 sebanyak 36 objek pajak parkir dan tahun 2017 sebanyak 93 objek pajak parkir di Provinsi DKI Jakarta sudah tidak beroperasi lagi .

\section{Target dan Realisasi Pajak Restoran Provinsi DKI Jakarta}

Berikut ini adalah target dan realisasi pajak restoran Provinsi DKI Jakarta tahun 20152017

Tabel 9

Target dan Realisasi Pajak Restoran Provinsi DKI Jakarta

Tahun 2015 - 2016

\begin{tabular}{|c|c|c|}
\hline Tahun & Target (Rp) & Realisasi (Rp) \\
\hline 2015 & 2.100 .000 .000 .000 & 2.290 .255 .418 .530 \\
\hline
\end{tabular}

\begin{tabular}{|l|l|l|}
\hline 2016 & 2.600 .000 .000 .000 & 2.453 .440 .079 .189 \\
\hline 2017 & 2.700 .000 .000 .000 & 2.752 .068 .115 .536 \\
\hline
\end{tabular}

Sumber ( Laporan Keuangan Pemerintah Daerah Provinsi DKI Jakarta)

Berdasarkan tabel 9 realisasi Pajak Restoran tahun anggaran 2015 adalah Rp. 2.290.255.418.530 dari target yang ditetapkan sebesar Rp. 2.100.000.000.000. Realisasi Pajak Restoran tahun anggaran 2016 adalah sebesar Rp. 2.453.440.079.189 dari target yang ditetapkan sebesar Rp. 2.600.000.000.000. Realisasi tersebut mengalami peningkatan sebesar Rp. 163.184.660.659 jika dibandingkan dengan realisasi Pajak Restoran tahun anggaran 2015 sebesar Rp. 2.290.255.418.530. Namun realisasi Pajak Restoran tahun anggaran 2016 tersebut belum mencapai target yang ditetapkan. Realisasi Pajak Restoran tahun anggaran 2017 adalah sebesar Rp. 2.752.068.115.536 dan target yang ditetapkan sebesar Rp. 2.700.000.000.000. Realisasi tersebut mengalami peningkatan sebesar Rp. 298.628.036.347 jika dibandingkan dengan realisasi Pajak Restoran tahun anggaran 2016 sebesar Rp. 2.453.440.079.189.

Berdasarkan hasil wawancara dengan Badan Pajak dan Retribusi Daerah Provinsi DKI Jakarta dengan Bidang Perencanaan dan Pengembangan, dalam menentukan target atau potensi Pajak Restoran DKI Jakarta menggunakan rumus yang telah ditetapkan pada Surat Keputusan Kepala Dinas Pelayanan Pajak Provinsi DKI

Jakarta nomor 376 tahun 2013 yaitu

\section{$(\mathrm{M}+\mathrm{P})$ x N x 365 hari $x$ Tarif Pajak} Restoran

\section{Keterangan :}

M = Harga Rata-Rata Makanan Per Orang

$\mathrm{P} \quad=$ Harga Rata-Rata Minuman Per Orang

$\mathrm{N} \quad=$ Jumlah Rata-Rata Pengunjung ( $\sum$ Kursi x AR x Jam Efektif) + ( $\sum$ Kursi x AR x Jam Tidak Efektif)

Berdasarkan hasil wawancara dengan Badan Pajak dan Retribusi Daerah dengan 
Bidang Perencanaan dan Pengembangan, tidak tercapainya realisasi penerimaan Pajak Restoran dikarenakan turunnya daya beli masyarakat yang disebabkan oleh faktor ekonomi dan belum efektifnya pelaksanaan penagihan pajak dengan surat paksa.

\section{Pembahasan}

Untuk menghitung besarnya kontribusi Pajak Parkir terhadap Pendapatan Asli Daerah (PAD) adalah dengan membandingkan realisasi penerimaan Pajak Parkir dengan realisasi Pendapatan Asli Daerah (PAD). Besarnya kontribusi Pajak Parkir dalam rangka meningkatkan Pendapatan Asli Daerah (PAD) Jakarta Timur tahun 2015-2017 dapat dilihat pada tabel berikut ini

Tabel 10

Kontribusi Pajak Parkir Dalam Rangka Meningkatkan Pendapatan Asli Daerah (PAD) Kota Administrasi Jakarta Timur Tahun

2015-2017

\begin{tabular}{|c|c|c|c|c|}
\hline Tahun & $\begin{array}{c}\text { Realisasi Pajak } \\
\text { Parkir (Rp) }\end{array}$ & $\begin{array}{c}\text { Realisasi PAD } \\
\text { Jakarta Timur } \\
\text { (Rp) }\end{array}$ & $\begin{array}{c}\text { Kontribusis } \\
(\%)\end{array}$ & $\begin{array}{c}\text { Kriteria } \\
\text { Kontribusisi }\end{array}$ \\
\hline 2015 & 21.933 .058 .028 & $2.872 .8866 .648 .549,53$ & 0,76 & Sangat Kurang \\
\hline 2016 & 28.167.206.549 & $3.419,523,615,902,00$ & 0,82 & Sangat Kurang \\
\hline 2017 & 41.486 .376 .306 & $3.819 .775 .386 .632,02$ & 1,08 & Sangat Kurrang \\
\hline \multicolumn{3}{|c|}{ Rata-rata } & 0,88 & Sangat Kurrang \\
\hline
\end{tabular}

Sunber: Datad diolah pentlis (2018)

Berdasarkan tabel 10 kontribusi Pajak Parkir dari tahun 2015 sampai tahun 2017 dalam rangka meningkatkan Pendapatan Asli Daerah (PAD) Jakarta Timur mengalami peningkatan.
Dari data diatas diketahui tingkat kontribusi Pajak Parkir tahun 2015 sampai dengan tahun 2017 yaitu, Rp. 21.933.058.028 dengan persentase kontribusi $0,76 \%$ pada tahun 2015, Rp. 28.167.206.549 dengan persentase kontribusi $0,82 \%$ pada tahun 2016, dan Rp. 41.486.376.306 dengan persentase kontribusi 1,08\% pada tahun 2017. Tahun 2017 merupakan kontribusi terbesar Pajak Parkir terhadap PAD Jakarta Timur. Dari data tersebut diketahui kontribusi Pajak Parkir terhadap PAD Jakarta Timur mengalami peningkatan, namun rata-rata kontribusinya yaitu sebesar $0,88 \%$. Berdasarkan klasifikasi kriteria kontribusi persentase $0,00 \%$ $10 \%$ masuk dalam kriteria sangat kurang. Artinya bahwa kontribusi yang diberikan oleh Pajak Parkir dalam rangka meningkatkan Pendapatan Asli Daerah (PAD) Jakarta Timur tahun 20152017 masuk dalam kriteria "Sangat Kurang".

Berdasarkan hasil wawancara dengan Suku Badan Pajak dan Retribusi Daerah Jakarta Timur dengan Bidang Penetapan dan Penagihan beberapa faktor penyebab kontribusi yang masih sangat kurang dikarenakan adanya proyek pembangunan infrastruktur pemerintah yang mempengaruhi okupansi lahan parkir sehingga mengakibatkan 13 objek pajak parkir di Jakarta Timur sudah tidak beroperasi kembali, tingkat kesadaran masyarakat untuk membayar pajak masih rendah dikarenakan masih minimnya pengetahuan dan informasi tentang pajak sehingga mengakibatkan kontribusi yang diberikan Pajak Parkir dalam rangka meningkatkan Pendapatan Asli Daerah (PAD) Jakarta Timur masih sangat kurang.

\section{Analisis Kontribusi Pajak Restoran Dalam Rangka Meningkatkan Pendapatan Asli Daerah (PAD) Kota Administrasi Jakarta Timur Tahun 2015-2017}

Untuk menghitung besarnya kontribusi Pajak Restoran terhadap Pendapatan Asli Daerah (PAD) adalah dengan membandingkan realisasi penerimaan Pajak Restoran dengan realisasi Pendapatan Asli Daerah (PAD). Besarnya kontribusi Pajak Restoran dalam rangka meningkatkan Pendapatan Asli Daerah (PAD) Jakarta Timur tahun 2015-2017 dapat dilihat pada tabel berikut ini

\section{Tabel 11}




\section{Kontribusi Pajak Restoran Dalam Rangka Meningkatkan Pendapatan Asli Daerah (PAD) Jakarta Timur}

Tahun 2015-2017

\begin{tabular}{|c|c|c|c|c|}
\hline Tahun & $\begin{array}{l}\text { Realisasi Pajak } \\
\text { Restoran } \\
\text { (Rp) }\end{array}$ & $\begin{array}{l}\text { Realisasi PAD } \\
\text { Jakarta Timur } \\
\text { (Rp) }\end{array}$ & $\begin{array}{c}\text { Kontribus } \\
\mathrm{i}(\%)\end{array}$ & $\begin{array}{c}\text { Kriteria } \\
\text { Kontribusi }\end{array}$ \\
\hline 2015 & 120.367 .066 .166 & 2.872.886.648.549,53 & 4,18 & Sangat Kurang \\
\hline 2016 & 156.577 .884 .159 & 3.419,523.615.902,00 & 4,57 & Sangat Kurang \\
\hline 2017 & 225.860 .742 .835 & $3.819 .775 .386 .632,02$ & 5,91 & Sangat Kurang \\
\hline \multicolumn{3}{|c|}{ Rata-rata } & 4,88 & Sangat Kurang \\
\hline
\end{tabular}

Sumber : Data diolah penulis (2018)

Berdasarkan tabel XI kontribusi Pajak Restoran dari tahun 2015 sampai tahun 2017 dalam rangka meningkatkan Pendapatan Asli Daerah (PAD) Jakarta Timur mengalami peningkatan.

Dari data diatas diketahui tingkat kontribusi Pajak Restoran tahun 2015 sampai dengan tahun 2017 yaitu Rp. 120.367.066.166 dengan persentase kontribusi $4,18 \%$ pada tahun 2015, Rp. 156.577.884.159 dengan persentase kontribusi $4,57 \%$ pada tahun 2016, dan Rp. 225.860.742.835 dengan persentase kontribusi 5,91\% pada tahun 2017. Tahun 2017 merupakan kontribusi terbesar Pajak Restoran terhadap PAD Jakarta Timur. Dari data tersebut diketahui kontribusi Pajak Restoran terhadap Pendapatan Asli Daerah (PAD) Jakarta Timur mengalami peningkatan, namun rata-rata kontribusinya yaitu sebesar $4,88 \%$. Berdasarkan klasifikasi kriteria kontribusi persentase $0,00 \%-10 \%$ masuk dalam kriteria sangat kurang. Artinya bahwa kontribusi yang diberikan Pajak Restoran dalam rangka meningkatkan Pendapatan Asli Daerah (PAD) Jakarta Timur tahun 2015-2017 masuk dalam kriteria "Sangat Kurang".

Berdasarkan hasil wawancara dengan Suku Badan Pajak dan Retribusi Daerah Jakarta Timur dengan Bidang Penetapan dan Penagihan beberapa faktor penyebab kontribusi yang masih sangat kurang dikarenakan belum efektifnya pelaksanaan penagihan pajak dengan surat paksa, pendataan potensi pertumbuhan objek pajak baru yang belum optimal sehingga mengakibatkan kontribusi yang diberikan Pajak Restoran dalam rangka meningkatkan Pendapatan Asli Daerah (PAD) Jakarta Timur masih sangat kurang
Analisis Kontribusi Pajak Parkir Jakarta Timur Terhadap Pendapatan Asli Daerah (PAD) DKI Jakarta Dalam Sektor Pajak Parkir Tahun 2015-2017

Untuk menghitung besarnya kontribusi yang diberikan Pajak Parkir Jakarta Timur terhadap Pendapatan Asli Daerah (PAD) DKI Jakarta dalam sektor Pajak Parkir dengan cara membandingkan realisasi penerimaan Pajak Parkir Jakarta Timur dengan realisasi Pajak Parkir DKI Jakarta pada tahun 2015-2017. Berikut tabel perhitungan kontribusi Pajak Parkir Jakarta Timur terhadap Pendapatan Asli Daerah (PAD) DKI Jakarta dalam sektor Pajak Parkir

\section{Tabel 12}

Kontribusi Pajak Parkir Jakarta Timur Terhadap Pendapatan Asli Daerah (PAD) DKI Jakarta Dalam Sektor Pajak Parkir Tahun 2015-2017

\begin{tabular}{|c|c|c|c|c|}
\hline Tahun & $\begin{array}{l}\text { Realisasi } \\
\text { Pajak Parkir } \\
\text { Jakarta } \\
\text { Timur } \\
\text { (Rp) }\end{array}$ & $\begin{array}{c}\text { Realisasi } \\
\text { Pajak Parkir } \\
\text { DKI Jakarta } \\
\text { (Rp) }\end{array}$ & $\begin{array}{c}\text { Kontribusi } \\
(\%)\end{array}$ & $\begin{array}{c}\text { Kriteria } \\
\text { Kontribusi }\end{array}$ \\
\hline 2015 & 21.933 .058 .028 & 450.941 .851 .356 & 4,86 & Sangat Kurang \\
\hline 2016 & 28.167 .206 .549 & 465.990 .849 .020 & 6,04 & Sangat Kurang \\
\hline 2017 & 41.486 .376 .306 & 484.833 .460 .923 & 8,55 & Sangat Kurang \\
\hline \multicolumn{3}{|c|}{ Rata-rata } & 6,48 & Sangat Kurang \\
\hline
\end{tabular}

Berdasarkan tabel 12 kontribusi Pajak Parkir Jakarta Timur dari tahun 2015 sampai tahun 2017 terhadap Pendapatan Asli Daerah (PAD) DKI Jakarta dalam sektor Pajak Parkir mengalami peningkatan.

Dari data diatas diketahui tingkat kontribusi Pajak Parkir Jakarta Timur tahun 2015 sampai dengan tahun 2017 yaitu Rp. 21.933.058.028 
dengan persentase kontribusi $4,86 \%$ pada tahun 2015, Rp. 28.167.206.549 dengan persentase kontribusi $6,04 \%$ pada tahun 2016, Rp. 41.486.376.306 dengan persentase kontribusi $8,55 \%$ pada tahun 2017. Dari angka tersebut diketahui bahwa kontribusi Pajak Parkir Jakarta Timur tahun 2015-2017 terhadap Pendapatan Asli Daerah (PAD) DKI Jakarta dalam sektor Pajak Parkir mengalami peningkatan, namun rata-rata kontribusinya yaitu sebesar $6,48 \%$. Berdasarkan klasifikasi kriteria kontribusi persentase $0,00 \%-10 \%$ masuk dalam kriteria sangat kurang. Artinya bahwa kontribusi yang diberikan Pajak Parkir Jakarta Timur terhadap Pendapatan Asli Daerah (PAD) DKI Jakarta dalam sektor Pajak Parkir tahun 2015-2017 masuk dalam kriteria "Sangat Kurang".

Faktor penyebab kontribusi masih sangat kurang dikarenakan adanya proyek pembangunan infrastruktur pemerintah tahun 2016-2017 yang mempengaruhi okupansi lahan parkir sehingga mengakibatkan 18 objek parkir di Jakarta Timur sudah tidak beroperasi lagi yaitu tahun 2016 sebanyak 5 objek pajak dan tahun 2017 sebanyak 13 objek pajak, adanya perubahan dasar pengenaan pajak, yaitu sebelumnya tarif pajak sudah termasuk pajak dan asuransi (included tax) kemudian menjadi tidak termasuk asuransi (excluded tax) dimana nilai tarif sebagai pengalinya mengalami penurunan, adanya pengurangan, keringanan, penghapusan, pembebasan, keberatan pajak dan angsuran pajak, tingkat kesadaran masyarakat untuk membayar pajak masih rendah dikarenakan masih minimnya pengetahuan dan informasi tentang pajak, dan belum maksimalnya pemungutan pajak parkir hal tersebut berkaitan dengan realisasi pengawasan peraturan daerah tentang pajak daerah yang relatif lemah.

\section{Analisis Kontribusi Pajak Restoran Jakarta Timur Terhadap Pendapatan Asli Daerah (PAD) DKI Jakarta Dalam Sektor Pajak} Restoran Tahun 2015-2017

Untuk menghitung besarnya kontribusi yang diberikan Pajak Restoran Jakarta Timur terhadap Pendapatan Asli Daerah (PAD) DKI Jakarta dalam sektor Pajak Restoran dengan cara membandingkan realisasi penerimaan Pajak Restoran Jakarta Timur dengan realisasi Pajak Restoran DKI Jakarta pada tahun 2015-2017.
Berikut tabel perhitungan kontribusi Pajak Restoran Jakarta Timur terhadap Pendapatan Asli Daerah (PAD) DKI Jakarta dalam sektor Pajak Restoran,

\section{Tabel 13}

Kontribusi Pajak Restoran Jakarta Timur Terhadap Pendepatan Asli Daerah (PAD) DKI Jakarta Dalam Sektor Pajak Restoran Tahun 2015-2017

\begin{tabular}{|c|c|c|c|c|}
\hline Tahun & $\begin{array}{c}\text { Realisasi Pajak } \\
\text { Restoran Jakaatta } \\
\text { Timur (Rp) }\end{array}$ & $\begin{array}{c}\text { Realisasi Pajak } \\
\text { Restoran DKI Jakatta } \\
\text { (Rp) }\end{array}$ & $\begin{array}{c}\text { Kontribusis } \\
(\%)\end{array}$ & $\begin{array}{c}\text { Krittria } \\
\text { Kontribusis }\end{array}$ \\
\hline 2015 & 120.367.066.166 & 2.290 .255 .418 .530 & 5,25 & Sangat Kurang \\
\hline 2016 & 156.577 .884 .159 & 2.453 .400 .079 .189 & 6,38 & Sangat Kurang \\
\hline 2017 & 225.860 .742 .835 & 2.752 .068 .115 .536 & 8,20 & Sangat Kurar \\
\hline \multicolumn{3}{|c|}{ Rata-rata } & 6,61 & Sangat Kưra \\
\hline
\end{tabular}

Sumber: Datat didah pendilis (2018)

Berdasarkan tabel 13 kontribusi Pajak Restoran Jakarta Timur dari tahun 2015 sampai tahun 2017 terhadap Pendapatan Asli Daerah (PAD) DKI Jakarta dalam sektor Pajak Restoran mengalami peningkatan.

Dari data diatas diketahui tingkat kontribusi Pajak Restoran Jakarta Timur tahun 2015 sampai dengan tahun 2017 yaitu Rp. 120.367.066.166 dengan persentase kontribusi $5,25 \%$ pada tahun 2015 , Rp. 156.577.884.159 dengan persentase kontribusi $6,38 \%$ pada tahun 2016, Rp. 225.860.742.835 dengan persentase kontribusi 8,20\% pada tahun 2017. Dari angka tersebut diketahui bahwa kontribusi Pajak Restoran Jakarta Timur tahun tersebut terhadap Pendapatan Asli Daerah (PAD) DKI Jakarta dalam sektor Pajak Restoran mengalami peningkatan, namun rata-rata kontribusinya yaitu sebesar $6,61 \%$. Berdasarkan klasifikasi kriteria kontribusi persentase $0,00 \%-10 \%$ masuk dalam kriteria sangat kurang. Artinya bahwa kontribusi yang diberikan Pajak Restoran Jakarta Timur terhadap Pendapatan Asli Daerah (PAD) DKI 
Jakarta dalam sektor Pajak Parkir tahun 20152017 masuk dalam kriteria "Sangat Kurang". Faktor penyebab kontribusi Pajak Restoran Jakarta Timur terhadap Pendapatan Asli Daerah (PAD) DKI Jakarta dalam sektor Pajak Restoran masih sangat kurang dikarenakan turunnya daya beli masyarakat karena faktor ekonomi, belum efektifnya pelaksanaan penagihan pajak dengan surat paksa, pendataan potensi pertumbuhan objek pajak baru yang belum optimal, tingkat kepatuhan dan kewajaran pembayaran dari wajib pajak yang belum optimal, dan pengurangan, keringanan, penghapusan, pembebasan, keberatan dan angsuran pajak.

\section{KESIMPULAN}

Berdasarkan penelitian dan pembahasan yang penulis lakukan maka kesimpulan dari hasil analisis dan pembahasan pada bab-bab sebelumnya dalah sebagai berikut :

1. Persentase kontribusi penerimaan yang diberikan Pajak Parkir dalam rangka meningkatkan Pendapatan Asli Daerah (PAD) Jakarta Timur selama tahun anggaran 2015 sampai tahun 2017 untuk setiap tahunnya adalah untuk tahun 2015 yaitu $0,76 \%$, tahun 2016 yaitu $0.82 \%$, dan untuk tahun 2017 yaitu 1,08\%. Tahun 2017 merupakan kontribusi terbesar Pajak Parkir terhadap PAD Jakarta Timur. Kontriibusi Pajak Parkir terhadap PAD Jakarta Timur tahun anggaran 2015 sampai tahun 2017 mengalami peningkatan setiap tahunnya, namun kriteria kontribusinya "Sangat Kurang" berdasarkan hasil rata-rata kontribusi Pajak Parkir tahun 2015 sampai tahun 2017 yaitu sebesar $0,88 \%$.

2. Persentase kontribusi penerimaan yang diberikan Pajak Restoran dalam rangka meningkatkan Pendapatan Asli Daerah (PAD) Jakarta Timur selama tahun anggaran 2015 sampai tahun 2017 untuk setiap tahunnya adalah tahun 2015 yaitu 4,18\%, tahun 2016 yaitu 4,57\%, dan untuk tahun 2017 yaitu 5,91\%. Tahun 2017 merupakan kontribusi terbesar Pajak Restoran terhadap PAD Jakarta Timur. Kontribusi Pajak Restoran terhadap PAD Jakarta Timur tahun anggaran 2015 sampai tahun 2017 mengalami peningkatan setiap tahunnya, namun kriteria kontribusinya "Sangat
Kurang" berdasarkan rata-rata kontribusi Pajak Restoran tahun 2015 sampai tahun 2017 yaitu sebesar $4,88 \%$.

3. Persentase kontribusi Pajak Parkir dalam rangka meningkatkan Pendapatan Asli Daerah (PAD) dalam sektor Pajak Parkir di DKI Jakarta selama tahun anggaran 2015 sampai tahun 2017 untuk setiap tahunnya adalah untuk tahun 2015 yaitu $4,86 \%$, tahun 2016 yaitu $6,04 \%$, dan untuk tahun 2017 yaitu 8,55\%. Tahun 2017 merupakan kontribusi terbesar Pajak Parkir dalam rangka meningkatkan Pendapatan Asli Daerah (PAD) dalam sektor Pajak Parkir di DKI Jakarta, kontribusinya mengalami peningkatan setiap tahunnya , namun kriteria kontribusinya "Sangat Kurang" berdasarkan hasil rata-rata kontribusi Pajak Parkir tahun 2015 sampai tahun 2017 yaitu sebesar 6,48\%.

2. Persentase kontribusi Pajak Restoran dalam rangka meningkatkan Pendapatan Asli Daerah (PAD) dalam sektor Pajak Restoran di DKI Jakarta selama tahun anggaran 2015 sampai tahun 2017 untuk setiap tahunnya adalah untuk tahun 2015 yaitu 5,25\%, tahun 2016 yaitu $6,38 \%$, dan untuk tahun 2017 yaitu 8,20\%. Tahun 2017 merupakan kontribusi terbesar Pajak Restoran dalam rangka meningkatkan Pendapatan Asli Daerah (PAD) dalam sektor Pajak Restoran di DKI Jakarta, kontribusinya mengalami peningkatan setiap tahunnya, namun kriteria kontribusinya "Sangat Kurang" berdasarkan hasil rata-rata kontribusi Pajak Restoran tahun 2015 sampai tahun 2017 yaitu sebesar $6,61 \%$.

\section{SARAN}

Berdasarkan hasil penelitian dan pembahasan yang dilakukan penulis, maka sebagai bahan pertimbangan penulis mengemukakan saran sebagai berikut :

1. Pemerintah daerah Jakarta Timur harus dapat menerapkan sanksi yang tegas terhadap wajib pajak yang menunggak pajak seperti melakukan penyegelan dan penutupan tempat usaha karena menunggak agar tercapai efek jera bagi pelanggarnya.

2. Bagi Suku Badan Pajak dan Retribusi Daerah Jakarta Timur perlu melakukan pendataan ulang secara berkala terhadap wajib pajak 
parkir dan restoran, tidak hanya melihat dari yang SPTPD tetapi juga harus melihat kondisi lapangan untuk menjaring wajib pajak baru. Karena Pajak Parkir dan Pajak Restoran merupakan salah satu sumber penerimaan yang potensial di Jakarta Timur.

3. Perlu adanya sosialisasi tentang pentingnya kepatuhan dan kesadaran wajib pajak dalam melakukan pembayaran pajak sesuai waktu yang ditetapkan.

\section{DAFTAR PUSTAKA}

Adiningrat, Andi Arifwangsa, Subhan, dan M. N. 2017. Analisis Kontribusi Pemungutan Pajak Hotel dan Restoran Terhadap Pendapatan Asli Daerah Kota Makasar. Jurnal Perspektif, Volume. 2.

Agoes, Sukrisno. 2014. Akuntansi Perpajakan. Edisi 3. Jakarta: Salemba Empat

Ayza, B. 2017. Hukum Pajak Indonesia (Edisi Pert). Depok: Kencana.

Fadillah, J. L. 2015. Kontribusi dan Efektivitas Penerimaan Pajak Parkir Pada Pendapatan Asli Daerah Kota Semarang Tahun 20052014. Universitas Negeri Semarang.

Handoko P, Sri. 2013. Analisis Tingkat Efektivitas Pajak Daerah Sebagai Sumber Pendapatan Asli Daerah Kota Pontianak. http://jurnal.untan.ac.id/index.php/JEDA2/ar ticle/view/1361.Diaksespada tanggal 5 Agustus 2018 pukul 09.00 WIB

Ismiranti, M. P. 2016. Analisis Efisiensi, Efektivitas, dan Kontribusi Pajak Daerah dan Retribusi Daerah Terhadap Peningkatan Pendapatan Asli Daerah di Kota Surakarta Tahun 2009-2014. Universitas Muhammadiyah Surakarta.

Kamagi, Cornelin G, Jullie, dan Tressje. 2016. Analisis Kontribusi Pajak Daerah Terhadap Pendapatan Asli Daerah (PAD) di Kabupaten Minahasa Utara dan Kabupaten Minahasa Tenggara (Periode 2011-2015). Jurnal Berkala Ilmiah Efisiensi, Volume 16.

Laporan Keuangan Pemerintah Daerah (LKPD)
Provinsi DKI Jakarta. 2015. Provinsi DKI Jakarta.

Laporan Keuangan Pemerintah Daerah (LKPD) Provinsi DKI Jakarta. 2016. Provinsi DKI Jakarta.

Laporan Keuangan Pemerintah Daerah (LKPD) Provinsi DKI Jakarta. 2017. Provinsi DKI Jakarta.

Mardiasmo. 2016. Perpajakan (Edisi Terb). Yogyakarta: Andi.

Nela, W. O. 2016. Analisis Kontribusi Pajak Hotel dan Pajak Restoran dan Retribusi Daerah Dalam Meningkatkan Pendapatan Asli Daerah Kabupaten Muna Tahun 20102015. Universitas Halu Oleo.

Pekei, B. 2016. Konsep Dan Analisis Efektifitas Pengelolaan Keuangan Daerah Di Era Otonomi. Jakarta: Taushia.

Peraturan Daerah Provinsi DKI Jakarta Nomor 11 Tahun 2011 tentang Pajak Restoran, No. 11 2011.

Peraturan Daerah Provinsi DKI Jakarta Nomor 16 Tahun 2010 tentang Pajak Parkir, No. 16 2010.

Peraturan Daerah Provinsi DKI Jakarta Nomor 6 Tahun 2010 tentang Ketentuan Umum Pajak Daerah, No. 62010.

Peraturan Pemerintah Nomor 55 Tahun 2016 tentang Ketentuan Umum dan Tata Cara Pemungutan Pajak Daerah, No. 552016.

Putra, I. M. 2017. Perpajakan (Tax Amnest). Yogyakarta: Quadrant.

Resmi, S. 2017. Perpajakan (Edisi 10). Jakarta: Salemba Empat.

Samudra, A. A. 2015. Keuangan, Pajak dan Retribus Daerah. Jakarta: Raja Grafindo Persada.

Sari, D. 2013. Konsep Dasar Perpajakan. Bandung: PT. Refika Aditama. 
Surat Keputusan Kepala Dinas Pelayanan Pajak Provinsi DKI Jakarta nomor 376 tahun 2013, No. 376

TMbooks. 2016. Perpajakan Indonesia. Yogyakarta: Andi.

Undang-Undang No. 16 Tahun 2009 tentang Ketentuan Umum dan Tata Cara Perpajakan, No. 282009.

Undang-Undang Nomor 32 Tahun 2004 tentang Pemerintah Daerah, No. 32. 2004.

Undang-Undang Republik Indonesia Nomor 28 Tahun 2009 tentang Pajak Daerah dan Retribusi Daerah, No. 28. 2009.

Undang-Undang Republik Indonesia Nomor 33 Tahun 2004 tentang Perimbangan Keuangan antara Pemerintah Pusat dan Daerah, No. 33. 2004.

Waluyo. 2017. Perpajakan Indonesia. (Edisi 12). Jakarta: Salemba Empat.

Yani, A. 2013. Hubungan Keuangan Antara Pemerintah Pusat dan Daerah Di IndonesiaHubungan Keuangan Antara Pemerintah Pusat dan Daerah diIndonesia (Edisi Revi). Jakarta: Rajawali. 